\title{
School Librarian Leadership: Research and Practice
}

\author{
Nancy Everhart \\ Professor \\ Florida State University \\ iSchool \\ Tallahassee, FL USA \\ everhart@fsu.edu \\ Melissa P. Johnston \\ Assistant Professor \\ University of Alabama \\ School of Library \& Information Studies \\ Tuscaloosa, AL USA \\ mpjohnston@slis.ua.edu
}

\begin{abstract}
A core body of research concerning teacher librarian leadership has been generated by faculty and doctoral graduates from Florida State University. Substantive studies have been conducted on leadership in technology integration by National Board Certified teacher librarians, enablers and barriers to technology leadership by teacher librarians, leadership in state initiatives related to digital textbooks, leadership with e-books and electronic devices, one-to-one computing, and school librarian leadership education. This paper provides an overview of that research and presents implications for teacher librarian education.
\end{abstract}

Keywords: teacher librarianship, leadership, teacher librarian preparation programs, technology integration

\section{Introduction}

The ever-increasing presence of technology has resulted in major changes in education in the 21 st century and has significantly redefined the role of the teacher librarian (Everhart, Johnston, \& Mardis, 2011). Digital learning technologies and resources have led to changes in the potential of teacher librarians as schools search for ways to deal with and integrate technology for learning (Johnston, 2015). Schools are now turning to teacher librarians to become an essential part of effectively integrating digital technologies and resources to improve student outcomes (Wolf, Jones, \& Gllbert, 2014).

The guidelines of the profession in the United States, Empowering Learners: Guidelines for School Library Media Programs (AASL, 2009), place an emphasis on technology and direct teacher librarians "to play a leading role in weaving such skills throughout the curriculum so that all members of the school community are effective users of ideas and information" 
(AASL, 2009, p. 46). It is this "weaving" or the integration of technology into the curricular areas where teacher librarians, based on their knowledge of pedagogical principles and school curriculum, technology expertise, and collaborative experience, can serve as leaders and valuable assets to their schools (Johnston, 2012). These standards further assert that with the changing information landscape of the 21 st century that includes interactive technologies and a participatory culture, teacher librarians must evolve as leaders to address the needs of this new generation of learners. Providing leadership in technology integration for the purposes of learning is paramount, and responsibility for leading this movement - to prepare learners for participating and succeeding in future global society - is more frequently being placed with teacher librarians.

While the number of teachers utilizing technology and digital resources in their classroom is increasing, there are still issues with effectively integrating and appropriately utilizing them to present new opportunities for student learning (Common Sense Media, 2013; Mardis, ElBasri, Norton, \& Newsum, 2012; Project Tomorrow 2012). A majority of teachers struggle to find the digital resources they need (Common Sense Media, 2013) and research shows that educators are regularly frustrated when seeking digital resources to support the needs of a variety of students (Common Sense Media, 2013; Mardis et al., 2012). It is this frustration that continues to lead to the underutilization of digital resources by educators even though they are aware of the importance and usefulness (Common Sense Media, 2013; Diekema \& Olsen, 2012); demonstrating that teachers are in need of professional development in utilizing digital content in their classrooms (Project Tomorrow, 2014). Classroom teachers need assistance in harnessing the new technology and digital tools for both teaching and learning (Common Sense Media, 2013; Duke \& Ward, 2009; Mardis et al., 2012). This provides an opportunity for teacher librarians to assume a leadership role - to be the person that the teachers in their building rely on to help them find digital resources and also to teach them how to utilize them effectively. Teacher librarians must be taught how to add this ever increasingly important role of staff developer to their repertoire of skills.

The Partnerships for Advancing Library Media (PALM) Center at Florida State University (FSU), through funding from Institute of Museum and Library Services (IMLS) projects such as Project Leaders Educated to Make a Difference (LEAD), Project 1-2-3 LEAD, and Project Leadership in Action (LIA), has been able to fund multiple projects and support for students' doctoral studies. Project LEAD was a master's in library and information science (MLIS) leadership curriculum developed for teacher librarians, with emphases on technology integration, instructional leadership, leadership in reading, and organizational leadership based on the tenets of the National Board for Professional Teaching Standards Certification in Library Media. Project 1-2-3 LEAD enabled a cohort of 30 outstanding teachers to complete a curriculum and engage in this curriculum and further leadership activities as part of earning an MLIS degree (Everhart \& Mardis, 2014). These projects, along with the research of faculty, and the funded students, have focused on researching the teacher librarian's role as a leader in technology integration. Faculty and doctoral graduates from FSU have generated a core body of research concerning teacher librarian leadership. Substantive studies have been conducted on leadership in technology integration by National Board Certified teacher librarians, enablers and barriers to technology leadership by teacher librarians, leadership in-state initiatives related to digital textbooks, leadership with e-books and electronic devices, one-to-one computing, and teacher librarian leadership education. 
This paper will review these studies and present implications for the education of future teacher librarians.

\section{Developing a Leadership Curriculum: A Research Based Approach}

In the 1998 update of Information Power: Building Partnerships for Learning (AASL \& AECT, 1998 ) the teacher librarian was defined as an "advocate for integrating information literacy skills in instruction of the curricular areas" and that "as a leader the school library media specialist promotes the use of technology" (p. 54). While leadership was established as an essential element for competent teacher librarians, teacher librarian preparation programs still struggled with how to best prepare future teacher librarians for this role. Researchers at FSU saw this as an opportunity to examine possible ways to integrate a stronger leadership component into the teacher librarian preparation curriculum (Everhart \& Dresang, 2007). They determined that The National Board for Professional Teaching Standards tenets, which focus on encouraging organizational leadership, provided a natural foundation for curriculum development. Since the research showed that National Board certified teachers, on average, are more involved leadership activities in their schools and the process itself is a leadership activity (NBPTS, 2001), Everhart and Dresang (2007) set the second goal of the new curriculum to prepare interested teacher librarians to demonstrate their leadership through National Board Certification. "National Board Certification, a voluntary process, is overseen by the National Board for Professional Teaching Standards, a non-profit, non-partisan organization, and is the highest credential in the teaching profession" (Everhart \& Dresang, 2007, p. 273). Grant support for increasing institutional capacity from the Institute of Museum and Library Services, Project LEAD: Leaders Educated to Make a Difference, gave faculty the time and resources to develop a based-on-research curriculum.

Everhart and Dresang based their research on three questions: "How does systematic, indepth research make a difference in course development?; To what extent will it validate what faculty would have done without it and to what extent does it change what would have been done?; and Is there a need for leadership courses based on National Board tenets?" (Everhart \& Dresang, 2007, p. 274). In order to investigate curriculum development in this area and answer their research questions multiple methods were employed. First an extensive review of the literature in the areas of teachers' leadership and National Board certification, teacher librarian leadership, and impact of national board certification in relation to student achievement was conducted. The nascent data that had been collected on those teacher librarians that had completed the National Board certification process was also examined. Additionally, both researchers gathered informal data from successful and unsuccessful candidates through their participation on the National Board for Professional Teaching Standards electronic discussion group. Next, a survey was conducted with a sample of successful candidates to determine what types of supports those successfully completing the process valued. In order to obtain the views of those who were unsuccessful candidates, the researchers interviewed five unsuccessful candidates. Finally, local and national advisory boards composed of members experienced in the National Board process and were established (Everhart \& Dresang, 2007).

Everhart and Dresang (2007) found seven prominent themes in their needs assessment important to consider in the development of the program and curriculum. First was the importance of the National Board learning community as a support. This community including mentors, electronic listservs, and online discussion groups provided valuable support to 
candidates as they progressed through the process. The element of collaboration is a required portfolio entry in the National Board process. This requirement helped candidates reshape their definition of collaboration between the teacher librarian and teachers and also illuminated the need for further instruction in this area. Candidates are expected to demonstrated leadership throughout the process, but must document how their leadership in the school, the professional arena, and the community has positively impacted student achievement in the portfolio entry dedicated to leadership. One of the more surprising elements was the need for help with teaching literature appreciation. The third portfolio entry focuses on the integration of technology to support instruction results indicated that more knowledge of instructional techniques and pedagogy was needed in order to effectively integrate technology. The fifth element was analytical and reflective practice where respondents noted to need to improve reflective thinking and the analytical writing skills needed to be a successful candidate. Race/ethnicity issues also emerged from the data with $90.2 \%$ of respondents being white designating a need for diversity in recruitment.

The research supported the need for developing this type of curriculum. The analysis and application of this needs assessment led to the development of a "12-credit completely online leadership curriculum at the Florida State University College of Information offered as part of the master's degree, or a specialist degree focused on leadership and the National Board, or as a stand alone certificate" (Everhart \& Dresang, 2007, p. 280).

\section{Implications for Teacher Librarian Education}

Everhart and Dresang's (2007) research served as the catalyst for major changes in the way that teacher librarians in the United States are educated. It established a completely online curriculum based on leadership, National Board tenets, and the needs of the profession. The curriculum consists of four courses: Leadership in Reading, Leadership in Technology, Information Leadership, and The Instructional Role of the Information Professional. As teacher librarian guidelines have evolved the leadership component has become an even more prominent aspect of preparing teacher librarians. This curriculum serves as a model on which to base other teacher librarian preparation curriculums and courses. Other findings from this research have implications for those educators preparing teacher librarians as well, such as the importance of having a community of support for learners. Teacher librarian educators can ensure that students can have places for open discussion, sharing of resources, and for providing support for each other. The wide reaching impact of this research is that provided the foundation for future grants to further investigate educating teacher librarians.

\section{Impact of Teacher Librarian Preparation Programs on Leadership Development}

The Project LEAD program taught the participants to model best practices and to exhibit leadership by emphasizing the principles of leadership. Elements of leadership were embedded into the curriculum through assignments and activities that required the participants to produce evidence of their leadership behaviors in their teaching practices, with fellow cohort members, and in self-reflection.

Smith (2009) surveyed Project LEAD participants upon the completion of the program in order to determine the factors that impacted the level of self-perceived transformational leadership potential of these pre-service teacher librarians. Her research was based on the following research questions: How did technology training facilitate leadership development 
in the participants?; How did the participants report using technology for school reform?; and How did the participants' use of technology differ from the typical teacher's reported use of technology in the state of Florida? The Leadership Practices Inventory (LPI) that measures transformational leadership (Kouzes \& Posner, 2007) was utilized by Smith (2009) to measure the five transformational leadership dimensions: Modeling the Way, Enabling Others to Act, Encouraging the Heart, Enabling Others to Act, Inspiring a Shared Vision, and Challenging the Process. These areas support the types of leadership goals that were taught during the Project LEAD program. Participants were also sent a second survey designed by Smith (2009) that included closed and open-ended questions designed to obtain demographic variables and the participants' perceptions of the skills they learned in each of the five transformational leadership dimensions. "Transformational leaders are role models who help to create shared visions by encouraging the individuals around them to achieve goals. They take risks to find proactive ways to solve problems. Most importantly, transformational leaders approach leadership by addressing individual strengths and needs" (Smith, 2010, p. 621).

Smith's (2009) findings indicated that the "participant's leadership training facilitated the development of their self-perceived transformational leadership behaviors to a significantly higher level than the established national norms for the LPI in two areas - Modeling the Way and Enabling Others to Act. Participants reported that they "acquir[ed] methods that allowed them to feel comfortable with being placed in leadership roles. They were confident that they could create positive impacts on their schools because of the leadership skills they learned" (Smith, 2010, p. 624). The participants' comments also indicated that the Project LEAD curriculum taught them to be transformational leaders by using technology, participants frequently indicated that the development of new technology skills gave them the confidence and knowledge to take on leadership roles and build their capacity for leading in the integration of technology for learning. Yet, even with this confidence, it was found that risktaking was still a challenge for these participants. Smith (2009) concluded that it was the technology and leadership skills students learned as a part of their preparation through Project LEAD that helped them to exemplify each of the five transformational leadership dimensions. This study indicates that teacher librarian preparation programs that place a great emphasis on technology integration and leadership can have a substantial impact on how technology is integrated into schools through creating confident teacher librarians that have the technology knowledge and the leadership skills to enact the expected leadership role in their school.

\section{Implications for Teacher Librarian Education}

As teacher librarians strive to meet the mission of ensuring the students and teachers are effective users of information, it has become apparent that leadership provides the way (AASL, 2009). The task of educating future teacher librarians to become these leaders is one that that falls to teacher librarian educators. Becoming a leader in one's school is not automatic or easy. It requires certain skills and training and teacher librarians need to be taught to learn about themselves and their potential to lead. This begins with teaching students to be self-aware of their strengths and weaknesses. The research by Smith proposes utilizing the Leadership Practices Inventory (LPI) as a measurement tool, but this instrument can be put in place in teacher library educator programs as a tool to help students become more aware of their own potential leadership style, as well as learning their own strengths and weaknesses so that they know areas in which they need to work on 
developing. A potential strategy would be to have students take the Leadership Practices Inventory at the beginning of their preparation program in order to provide them, as well as their instructors, a map to understanding their strengths and weaknesses. The identification of areas of potential weakness in areas of leadership practice will allow each student to develop a plan for their program to focus on learning the skills and strategies needed to address their area of weakness. It would also provide important information to instructors as they can use this information to further develop teacher librarian preparation programs that teach students to take advantage of their strengths in developing their leadership practices and that develop the areas of weakness by teaching students the valuable leadership skills they need. This research also illuminated the importance of mentors and the support they can provide to students and asserts that mentors should be incorporated within teacher librarian education programs.

\section{Individual Leadership - National Board Certified Teacher Librarians}

In 2010, the PALM Center conducted a national survey on how National Board Certified teacher librarians $(n=295)$ integrate technology into their school library programs with an emphasis on leadership roles (Everhart, Mardis \& Johnston, 2011). The study provided an initial attempt to characterize teacher librarians' technology integration activities in the contexts of what teacher librarians know, what they do, and how they grow as professionals tenets of the National Board process. In the U.S., National Board Certification is the highest credential in the teaching profession and those who achieve it are considered master educators. In order to achieve National Board Certification, these librarians had to successfully demonstrate their ability to integrate technology into instruction and document accomplishments in working with various communities-school, professional, and external.

The survey results indicated that these teacher librarians worked in affluent schools that offered them sufficient technology resources, support staff, and flexible scheduling. They were able to experience success with technology leadership with students to a great extent vis-a-vis using technology to pique learners' interest (95\%), aligning to professional and technology standards (93\%), differentiating instruction (87\%), modeling the use of technology $(79 \%)$ and teaching learners to identify the appropriate technology for their needs $(82 \%)$. Most respondents also were fully or substantially involved in helping learners create products using various technology $(72 \%)$ and facilitating learners' use of technology to express new ideas (70\%). Only $35 \%$ provided assistive and adaptive technologies for learners.

A large majority of respondents reported being fully or substantially involved in collaborating with teachers to use technology in their instruction (74\%), providing teachers with access to technology that enhances their instruction $(80 \%)$, promoting learning activities that connect technology to content standards (77\%), and advocating for the use of technology for alternative demonstrations of student learning (73\%). However, few respondents were fully or substantially involved in the initial process of setting learning objectives and promoting the integration of technology in classroom instruction (41\%) and even fewer respondents fully or substantially provided teachers with technological alternatives for assessing student learning (38\%).

When teacher librarian leaders were asked to report their technology leadership outside of their school buildings, they revealed much lower levels of involvement in district-wide policy 
making (57\%) and information sharing activities as well as in dissemination to peers at conferences (39\%) and to community members (55\%).

\section{Implications for Teacher Librarian Education}

Library educators (Harada \& Yoshima, 2006) have pointed to the fact most teacher librarians, even like the highly accomplished ones in this study, have difficulty setting learning objectives and assessing them. Much practice is needed in knowing what learning looks like, writing measurable learning outcomes, and actually developing rubrics and other tools that will take the focus from a teaching one to a learning one. LIS students can be given various scenarios, learning standards, or general goals to create concrete learning tasks and ways to measure them. They can be given self-assessment tools and also work with small groups of peers to critique each other's attempts. Faculty should also model this process by providing learning outcomes and the assessment tool that will be used for course assignments.

Since true collaboration involves co-planning, co-teaching, and co-assessing, students need to know what this looks like. Furnish examples of assessments that will be graded by the teacher librarian and discuss how teacher librarians can be formally involved in assessment. These usually entail grading the information search process, the quality of media products, and ethical use of information. Demonstrate tools that facilitate assessment such as google forms, polling, and citation managers (Fontichiaro, 2011). Have students role-play the collaboration process that involves creating objectives and assessing together either live or by creating a video.

The survey also revealed that teacher librarians might need help in learning how to share at conferences and with the community. By setting up case studies that would encourage community outreach activities, students can practice their creativity. Provide resources such as professional publications and even sites like Pinterest for ideas. As a class project, a realworld event can be planned and implemented. Give extra credit for attending conferences and reflecting on the speakers they see. Practice mini conference presentations for the class. Take it to another level and encourage them to submit a proposal to present at a conference or professional development day.

\section{Enablers and Barriers to Technology Leadership}

As technology permeates teaching and learning, teacher librarians are continually directed to assume a leadership role in integrating technology in schools from professional standards and guidelines, as well as from theorists and researchers in this area, yet this role is one that has been ignored in the research arena and left undefined for school administrators, teachers, and the teacher librarians themselves, leading to uncertainty concerning how teacher librarians enact this role in practice (Johnston, 2012). In efforts to further define this role the PALM Center at FSU constructed a survey, School Library Media Specialist and Technology Integration Survey (Everhart, Mardis, \& Johnston, 2011), based on extensive review of the literature in this area, set out to delineate the practices of technology integration leadership for teacher librarians. This survey sent out to National Board Certified teacher librarians across the United States was comprised of 30 demographic questions, 60 statements related to technology integration activities with response choices for statements that reflected respondents' degree of leadership regarding the particular integration activity: $0=$ Not my job; 1 =Rarely involved; $2=$ =Partially involved; $3=$ Substantially involved; $4=$ Fully 
involved, and three open-ended questions that asked respondents to discuss barriers, enablers, and other factors that influenced their leadership practices (Everhart, et al., 2011).

Johnston's research focused on two of the open-ended questions found at the end of the survey. These questions ask respondents to "Think back about the activities in the preceding statements, specifically those in which you are fully involved. What enables you to be involved at that level?" and "Again, think about those activities addressed earlier. Are there any activities in which you'd like to be more involved than you are right now? If so, please tell us about the barriers that hinder your involvement" (PALM, 2009). The purpose of Johnston's (2011) research was to identify what is enabling those most accomplished teacher librarians to thrive in the role of technology integration leader, as well as the barriers they face. In her research Johnston assumes that the leadership practices of teacher librarians are essentially those of teacher leaders and is bases her research on the educational leadership theory of distributed leadership, which asserts that that leadership is about more than just people in formal leadership positions and attempts to acknowledge all contributors, formal or informal, who participate in leadership practice pooling their abilities and expertise (Spillane, 2006). This view of leadership places emphasis on the importance of context and how it is a defining element of leadership practice, therefore it is necessary to understand how these aspects enable and constrain leadership practice.

The enablers and barriers were extracted from the text of the open-ended questions and content analysis was performed to code the data into categories using the a priori coding scheme taken from teacher leadership research, the Four Domains of Supports and Barriers to Teacher Leadership (Zinn, 1997). The content analysis and data coding resulted in the identification of the enablers and barriers teacher librarians experience in enacting a leadership role in technology integration. Johnston found that Relationships (Domain One) were found as frequently occurring enablers for accomplished teacher librarians' enacting a leadership role in technology integration, yet these same relationships can also constrain leadership enactment. These relationships include: principals, teachers, district administrators, other teacher librarians, and the instructional technologist. The world of education is full of formal and informal structures that can either support or constrain teacher leadership and this research found that the most frequently occurring barriers were in the area of Institutional Structure (Domain Two), including: leadership opportunities, professional development opportunities, and resources. The most frequently identified enablers identified were in the Intellectual and Psycho-social area (Domain Four). These enablers reflected the teacher librarians' willingness and ability to engage in a leadership role and assume responsibilities, and provide a teacher librarian with the beliefs, value system, desire to learn and grow professionally, and the confidence to support educators in leadership endeavors (Johnston, 2011). This research serves as the initial identification of enablers and barriers that accomplished teacher librarians experience when enacting, or attempting to enact, a technology integration leadership role.

\section{Implications for Teacher Librarian Education}

Findings from this study have implications for teacher librarian preparation programs. The ambiguity surrounding the technology integration leadership role has led to teacher librarians who are ill prepared to enact this vital role. The identification of the enablers and barriers that accomplished teacher librarians experience enacting a leadership role is valuable information for teacher library preparation professionals. Future teacher librarians can be taught how to 
identify enablers and develop strategies to use them to their advantage. Conversely, future teacher librarians can also be taught to identify barriers that even the most accomplished teacher librarians experience and develop strategies to reduce and overcome them in their future practice. The findings from this research can be useful for planning curriculum to better prepare teacher librarians to assume an active leadership role. Teacher librarian education program curricula need to include competencies that support the concept of teacher leadership and teach school librarians leadership skills such as effective communication, relationship building, problem solving, conflict resolution, time management, professional development, and other skills that will prepare them to assume leadership roles.

\section{School-Wide Leadership for the First Year Teacher Librarian}

In this study (Mardis \& Everhart, 2014), the researchers sought to investigate the experiences of new teacher librarians who had been educated in a leadership-focused master's degree program. Given the opportunities of this program, the researchers undertook to address a resulting central question: Did the graduates actually enact leadership roles when they became practicing teacher librarians?

The researchers prepared the participants to exercise leadership through Cooperative Inquiry. This group process was used to merge the viewpoints and experiences of teacher librarians, teachers, technology personnel, administrators, and other key school stakeholders in solving a mutually agreed-upon problem: What is an issue facing our school community that can be addressed with technology? With a budget of $\$ 6000$, they were told to mold that guiding question, with their team, to their own situation.

Each of the participants had varying levels of success. What worked was strategically inviting team members based on their unique abilities to represent a variety of perspectives, including the tech coordinator and principal on the team, making clear it is a group process, strong group facilitation by running well organized and focused meetings, group trust and respect, leading sensitive and diplomatic discussions, emphasizing group ownership, snacks, facilitating communication between meetings, and formal data collection throughout the process.

What didn't work was: disagreement about devices, ordering devices before clarifying the question to pursue, allowing members of the group to volunteer, lack of a shared purpose, relying on the teacher librarian to be the sole leader, and having the teacher librarian who used to be a teacher in the same school in a new role. All the participants, regardless of their level of success, embraced the process and planned on incorporating it in their own leadership style.

\section{Implications for Teacher Librarian Education}

Schools in the U.S. are hierarchical, driven by policy, and framed by concrete objectives and learning standards. Many teachers, hindered by scarce time and resources, are unsure how to participate in decision-making and inquiry. Cooperative Inquiry is a formal process (Heron, 1996) and using this as a framework for educating school library leaders provides them with skills such as how to be an effective listener, facilitation, diversifying and focusing a group, asking engaging questions, discussing scenarios, and reflection. 
Leadership is also about confidence, and leadership education gave these students the confidence to tackle their new positions as teacher librarians. Taken from the business world, techniques do exist for teaching confidence such as SWOT (strengths, weaknesses, opportunities and threats) analysis. A workshop was held for Project LEAD students and the workshop speakers discussed how to receive a compliment properly, taking a Myers-Briggs test and matching with a person with whom you would work well, and how to be persuasive using strategic touch.

Data collection also helped these students feel more confident. Provide models of wellwritten reports and representations of data. Demonstrate tools that create infographics as they can be a dynamic tool. Discuss how using engaging quotes can be as powerful as large-scale data. Group exercises on planning strategies that would track a small group of students over a longer period in order to delve more deeply into their findings would also be helpful.

\section{District-Wide Leadership with Broadband}

Teacher librarians see the use of technology and connectivity at both the desktop and district levels and have knowledge of not only the issues inherent in instructional integration but also technology infrastructure. In their roles as school leaders, teacher librarians provide tech coordination, support, and the leadership necessary to address access issues from desktop to district. But they will have difficulty performing this leadership role if broadband speed and connectivity are insufficient. In a white paper, (Everhart, Mardis, Johnston, \& Smith, 2009) these related issues were examined:

1. Students need high speed broadband to access in their schools to take advantage of a wide range of new and rich educational resources available for anytime, anywhere learning.

2. Teachers need high-speed broadband access for professional development and engaging in professional learning communities as well as accessing new educational resources.

3. Administrators need high-speed broadband to conduct online assessments and access data for effective decision-making.

4. Students need high-speed broadband to overcome the digital divide in rural areas (Everhart, Mardis, Johnston \& Smith, 2009).

A solution to these situations is on-site support to streamline and enable effective use of broadband-enabled technology. For most schools, the teacher librarian can expertly direct this "last mile" implementation in broadband access, skill, policy, and motivation. Table 1 depicts the ways in which teacher librarians are very involved in supporting effective use of broadband in all areas in all of their roles to Florida's education stakeholders.

\begin{tabular}{|l|l|l|l|l|l|}
\hline & Teacher & $\begin{array}{l}\text { Instructional } \\
\text { Partner }\end{array}$ & $\begin{array}{l}\text { Resource } \\
\text { Specialist }\end{array}$ & \multicolumn{1}{|c|}{$\begin{array}{l}\text { Program } \\
\text { Leader }\end{array}$} & Even Further \\
\hline Access & $\begin{array}{l}\text { Promote } \\
\text { awareness of } \\
\text { Web 2.0 and }\end{array}$ & $\begin{array}{l}\cdot \text { Co-plan, } \\
\text { co-teach, } \\
\text { and co- }\end{array}$ & $\begin{array}{l}\bullet \text { Maintain } \\
\text { school } \\
\text { library }\end{array}$ & $\begin{array}{l}\text { - Determine } \\
\text { match } \\
\text { between }\end{array}$ & $\begin{array}{l}\text { - Use RSS } \\
\text { and push } \\
\text { technologies }\end{array}$ \\
\hline
\end{tabular}




\begin{tabular}{|c|c|c|c|c|c|}
\hline & Teacher & $\begin{array}{l}\text { Instructional } \\
\text { Partner }\end{array}$ & $\begin{array}{l}\text { Resource } \\
\text { Specialist }\end{array}$ & $\begin{array}{c}\text { Program } \\
\text { Leader }\end{array}$ & Even Further \\
\hline & $\begin{array}{l}\text { other } \\
\text { broadband- } \\
\text { enabled } \\
\text { applications } \\
\text { available in } \\
\text { the school } \\
\text { and school } \\
\text { library } \\
\text { - Support e- } \\
\text { portfolio } \\
\text { creation by } \\
\text { students }\end{array}$ & $\begin{array}{l}\text { assess } \\
\text { assignments } \\
\text { that make } \\
\text { effective use } \\
\text { of } \\
\text { broadband } \\
\text { enabled } \\
\text { applications } \\
\text { and digital } \\
\text { resources } \\
\text { • Ensure } \\
\text { equal } \\
\text { access for } \\
\text { all students, } \\
\text { subject } \\
\text { areas, and } \\
\text { grade levels } \\
\text { via } \\
\text { curriculum } \\
\text { mapping } \\
\text { and sharing } \\
\text { connections } \\
\text { and overlap } \\
\text { with } \\
\text { teachers } \\
\text { - Develop } \\
\text { unique } \\
\text { electronic } \\
\text { resources to } \\
\text { supplement } \\
\text { curriculum }\end{array}$ & $\begin{array}{l}\text { website to } \\
\text { allow 24-7 } \\
\text { access to } \\
\text { catalog and } \\
\text { databases } \\
\text { from home } \\
\text { and other } \\
\text { locations } \\
\text { - Locate } \\
\text { sources of } \\
\text { free digital } \\
\text { video, } \\
\text { learning } \\
\text { objects and } \\
\text { e-books to } \\
\text { integrate } \\
\text { into catalog } \\
\text { - Correlate } \\
\text { physical and } \\
\text { digital } \\
\text { resources to } \\
\text { school } \\
\text { textbook } \\
\text { series in } \\
\text { OPAC }\end{array}$ & $\begin{array}{l}\text { desktop and } \\
\text { district } \\
\text { connectivity } \\
\text { speeds as } \\
\text { well as } \\
\text { desktop } \\
\text { computer } \\
\text { adequacy as } \\
\text { part of } \\
\text { technology } \\
\text { planning } \\
\text { process } \\
\text { - Maintain } \\
\text { extended } \\
\text { hours in the } \\
\text { school library } \\
\text { - Facilitate } \\
\text { the } \\
\text { integration of } \\
\text { online course } \\
\text { offerings } \\
\text { - Serve as } \\
\text { an advocate } \\
\text { for student } \\
\text { access } \\
\text { - Develop } \\
\text { partnerships } \\
\text { to obtain } \\
\text { funding and } \\
\text { free } \\
\text { resources }\end{array}$ & $\begin{array}{l}\text { to make } \\
\text { teachers } \\
\text { aware of new } \\
\text { learning } \\
\text { resources } \\
\text { - Help } \\
\text { teachers to } \\
\text { develop and } \\
\text { tailor online } \\
\text { learning } \\
\text { options } \\
\text { - Design and } \\
\text { facilitate } \\
\text { online } \\
\text { interactions } \\
\text { with } \\
\text { students, } \\
\text { faculty and } \\
\text { experts in } \\
\text { remote } \\
\text { locations }\end{array}$ \\
\hline Skill & $\begin{array}{l}\text { - Design } \\
\text { professional } \\
\text { development } \\
\text { using latest } \\
\text { research } \\
\text { about } \\
\text { professional } \\
\text { development } \\
\text { for } \\
\text { technology } \\
\text { - Facilitate } \\
\text { after school }\end{array}$ & $\begin{array}{l}\text { - Co-teach } \\
\text { aspects of } \\
\text { revamped } \\
\text { lessons that } \\
\text { include } \\
\text { digital } \\
\text { resources, } \\
\text { broadband } \\
\text { applications, } \\
\text { and } 21^{\text {st }} \\
\text { Century } \\
\text { Skills }\end{array}$ & $\begin{array}{l}\text { - Collect a } \\
\text { variety of } \\
\text { tutorials and } \\
\text { just-in-time } \\
\text { PD } \\
\text { resources } \\
\text { - Work with } \\
\text { student } \\
\text { assistants to } \\
\text { create step- } \\
\text { by-step "job } \\
\text { aids" for }\end{array}$ & $\begin{array}{l}\text { - Survey } \\
\text { teachers on } \\
\text { professional } \\
\text { development } \\
\text { needs } \\
\text { - Seek own } \\
\text { professional } \\
\text { development } \\
\text { for network } \\
\text { administratio } \\
\mathrm{n} \text { and new } \\
\text { application }\end{array}$ & $\begin{array}{l}\text { - Promote a } \\
\text { collection of } \\
\text { "just in time" } \\
\text { professional } \\
\text { learning } \\
\text { digital videos } \\
\text { and } \\
\text { resources } \\
\text { - Incorporate } \\
\text { digital media } \\
\text { into school }\end{array}$ \\
\hline
\end{tabular}




\begin{tabular}{|c|c|c|c|c|c|}
\hline & Teacher & $\begin{array}{l}\text { Instructional } \\
\text { Partner }\end{array}$ & $\begin{array}{l}\text { Resource } \\
\text { Specialist }\end{array}$ & $\begin{array}{c}\text { Program } \\
\text { Leader }\end{array}$ & Even Further \\
\hline & $\begin{array}{l}\text { clubs for } \\
\text { students to } \\
\text { create media } \\
\text { and } \\
\text { participate in } \\
\text { online } \\
\text { learning } \\
\text { experiences }\end{array}$ & $\begin{array}{l}\text { - Provide } \\
\text { support and } \\
\text { professional } \\
\text { development } \\
\text { for } \\
\text { integration of } \\
\text { streaming } \\
\text { video } \\
\text { - Serve as a } \\
\text { model for } \\
\text { broadband } \\
\text { enabled } \\
\text { applications } \\
\text { in your own } \\
\text { instruction }\end{array}$ & $\begin{array}{l}\text { innovative } \\
\text { technology } \\
\text { activities like } \\
\text { video } \\
\text { creation }\end{array}$ & $\begin{array}{l}\text { use } \\
\text { - Educate } \\
\text { parents on } \\
\text { copyright, } \\
\text { safety, and } \\
\text { implications } \\
\text { of broadband }\end{array}$ & $\begin{array}{l}\text { television } \\
\text { production }\end{array}$ \\
\hline Policy & $\begin{array}{l}\text { - Educate } \\
\text { students and } \\
\text { teachers on } \\
\text { capacity } \\
\text { limitations, } \\
\text { copyright } \\
\text { and safety } \\
\text { implications } \\
\text { of broadband } \\
\text { applications } \\
\text { - Promote } \\
\text { digital } \\
\text { citizenship }\end{array}$ & $\begin{array}{l}\text { • Collect } \\
\text { information } \\
\text { about } \\
\text { instructional } \\
\text { events that } \\
\text { make use of } \\
\text { broadband } \\
\text { and present } \\
\text { in annual or } \\
\text { quarterly } \\
\text { reports to } \\
\text { administratio } \\
\text { n and school } \\
\text { board } \\
\text { - Participate } \\
\text { on } \\
\text { technology } \\
\text { planning } \\
\text { committees } \\
\text { that make } \\
\text { decisions } \\
\text { about } \\
\text { bandwidth, } \\
\text { equipment, } \\
\text { and } \\
\text { resources }\end{array}$ & $\begin{array}{l}\text { - Ensure that } \\
\text { collection } \\
\text { policy } \\
\text { pertains to } \\
\text { collecting } \\
\text { and } \\
\text { describing } \\
\text { digital } \\
\text { resources } \\
\text { - Develop } \\
\text { Acceptable } \\
\text { Use Policies } \\
\text { that include } \\
\text { Web } 2.0 \\
\text { applications }\end{array}$ & $\begin{array}{l}\text { - Determine } \\
\text { future } \\
\text { bandwidth } \\
\text { intensive } \\
\text { application } \\
\text { needs and } \\
\text { communicate } \\
\text { those to } \\
\text { district } \\
\text { personnel } \\
\text { - Review } \\
\text { compatibility } \\
\text { between } \\
\text { filtering } \\
\text { policies and } \\
\text { use of } \\
\text { bandwidth } \\
\text { intensive } \\
\text { applications. }\end{array}$ & $\begin{array}{l}\text { - Perform } \\
\text { ongoing } \\
\text { measuremen } \\
\text { ts of policy } \\
\text { impact and } \\
\text { adjust on an } \\
\text { ongoing } \\
\text { basis }\end{array}$ \\
\hline Motivation & $\begin{array}{l}\text { - Promote } \\
\text { Web } 2.0\end{array}$ & $\begin{array}{l}\text { - Share co- } \\
\text { teaching }\end{array}$ & $\begin{array}{l}\text { - Create an } \\
\text { online }\end{array}$ & $\begin{array}{l}\text { - Share } \\
\text { research on }\end{array}$ & $\begin{array}{l}\text { - Facilitate } \\
\text { an online }\end{array}$ \\
\hline
\end{tabular}




\begin{tabular}{|c|c|c|c|c|}
\hline Teacher & $\begin{array}{l}\text { Instructional } \\
\text { Partner }\end{array}$ & $\begin{array}{l}\text { Resource } \\
\text { Specialist }\end{array}$ & $\begin{array}{c}\text { Program } \\
\text { Leader }\end{array}$ & Even Further \\
\hline $\begin{array}{l}\text { applications } \\
\text { that make } \\
\text { good use of } \\
\text { bandwidth } \\
\text { and are } \\
\text { engaging for } \\
\text { learners }\end{array}$ & $\begin{array}{l}\text { successes } \\
\text { with digital } \\
\text { resources } \\
\text { and } \\
\text { broadband } \\
\text { applications } \\
\text { with other } \\
\text { teachers } \\
\text { - Facilitate } \\
\text { digital field } \\
\text { trips }\end{array}$ & $\begin{array}{l}\text { repository of } \\
\text { student- } \\
\text { created } \\
\text { digital work } \\
\text { - Set up } \\
\text { stations in } \\
\text { the library for } \\
\text { student } \\
\text { creations }\end{array}$ & $\begin{array}{l}\text { student } \\
\text { learning with } \\
\text { technology } \\
\text { - Collect and } \\
\text { share } \\
\text { school-based } \\
\text { data on } \\
\text { student } \\
\text { success with } \\
\text { technology }\end{array}$ & $\begin{array}{l}\text { community } \\
\text { for student } \\
\text { learners to } \\
\text { share ideas } \\
\text { and projects }\end{array}$ \\
\hline
\end{tabular}

Table 1. Teacher librarian leadership roles in broadband implementation.

\section{Implications for Teacher Librarian Education}

In order to ascertain the bandwith at specific computers, students can use connectivity calculators in a variety of locations and report on their findings. In this report, they can compare access speeds to what students and teachers will be able to accomplish with what is available. An extension of this activity would be to have them develop a persuasive presentation to administrators on the need to increase bandwith in their school district. Have students develop a collaborative lesson that includes a digital field trip or a Skype visit from an author or authority on some subject. In this lesson plan there could be a required section where they explore the bandwith and filtering implications for executing this type of exercise.

\section{Leadership in Top-Down State Initiatives}

Similar to the aforementioned white paper on broadband, our research group analyzed the status of the implementation of digital textbooks in schools and their advantages and disadvantages (Mardis, Everhart, Baker \& Newsum, 2010). Focusing on the state of Florida, where there is a state mandate to implement digital textbooks in all schools this coming year, we hypothesize that this is an area where teacher librarians can function as leaders serving as digital textbook managers and experts at identifying, collecting, and organizing the best digital content. Beyond those traditional tasks, there are opportunities to expand leadership to the same areas of access, skill, policy, and motivation as shown in Table 2.

\begin{tabular}{|l|l|l|l|l|l|}
\hline & Teacher & $\begin{array}{l}\text { Instructional } \\
\text { Partner }\end{array}$ & $\begin{array}{l}\text { Resource } \\
\text { Specialist }\end{array}$ & $\begin{array}{l}\text { Program } \\
\text { Leader }\end{array}$ & Even Further \\
\hline Access & $\begin{array}{l}\text { Promote } \\
\text { student } \\
\text { awareness of } \\
\text { digital } \\
\text { textbooks } \\
\text { and relevant } \\
\text { resources }\end{array}$ & $\begin{array}{l}\text { - Co-plan, } \\
\text { co-teach, } \\
\text { and co- } \\
\text { assess } \\
\text { assignments } \\
\text { that make } \\
\text { effective use }\end{array}$ & $\begin{array}{l}\text { - Maintain } \\
\text { school library } \\
\text { website to } \\
\text { allow 24-7 } \\
\text { access to } \\
\text { digital } \\
\text { textbooks }\end{array}$ & $\begin{array}{l}\text { Develop } \\
\text { partnerships } \\
\text { to obtain } \\
\text { funding and } \\
\text { free } \\
\text { resources } \\
\text { that enhance }\end{array}$ & $\begin{array}{l}\text { - Guide } \\
\text { teachers to } \\
\text { develop and } \\
\text { tailor online } \\
\text { learning } \\
\text { options that } \\
\text { enhance }\end{array}$ \\
\hline
\end{tabular}




\begin{tabular}{|c|c|c|c|c|c|}
\hline & Teacher & $\begin{array}{l}\text { Instructional } \\
\text { Partner }\end{array}$ & $\begin{array}{l}\text { Resource } \\
\text { Specialist }\end{array}$ & $\begin{array}{c}\text { Program } \\
\text { Leader }\end{array}$ & Even Further \\
\hline & $\begin{array}{l}\text { available in } \\
\text { the school } \\
\text { and school } \\
\text { library } \\
\text { - Promote } \\
\text { teacher } \\
\text { awareness of } \\
\text { digital } \\
\text { textbooks } \\
\text { and other } \\
\text { relevant } \\
\text { resources } \\
\text { available in } \\
\text { the school } \\
\text { and school } \\
\text { library }\end{array}$ & $\begin{array}{l}\text { of digital } \\
\text { textbooks } \\
\text { and relevant } \\
\text { resources. } \\
\text { - Ensure } \\
\text { equal access } \\
\text { for all } \\
\text { students } \\
\text { (including } \\
\text { those with } \\
\text { disabilities) } \\
\text { and teachers } \\
\text { via logon and } \\
\text { password } \\
\text { information, } \\
\text { and effective } \\
\text { ways for } \\
\text { printing } \\
\text { needed } \\
\text { information } \\
\text { - Ensure } \\
\text { equal access } \\
\text { for all } \\
\text { students and } \\
\text { teachers via } \\
\text { curriculum } \\
\text { mapping and } \\
\text { sharing } \\
\text { connections } \\
\text { and overlap } \\
\text { with teachers }\end{array}$ & $\begin{array}{l}\text { from home } \\
\text { and other } \\
\text { locations } \\
\text { - Locate } \\
\text { sources of } \\
\text { free, } \\
\text { downloadabl } \\
\text { e digital } \\
\text { video, } \\
\text { learning } \\
\text { objects and } \\
\text { e-books that } \\
\text { enhance } \\
\text { digital } \\
\text { textbooks to } \\
\text { and integrate } \\
\text { objects into } \\
\text { OPAC } \\
\text { - Correlate } \\
\text { physical and } \\
\text { digital } \\
\text { resources } \\
\text { relevant to } \\
\text { digital } \\
\text { textbooks in } \\
\text { OPAC } \\
\text { - Serve as a } \\
\text { testing and } \\
\text { experimental } \\
\text { center for } \\
\text { hardware } \\
\text { platforms. }\end{array}$ & $\begin{array}{l}\text { digital } \\
\text { textbook } \\
\text { lessons } \\
\text { - Maintain } \\
\text { extended } \\
\text { hours in the } \\
\text { school library } \\
\text { - Facilitate } \\
\text { the } \\
\text { integration of } \\
\text { online } \\
\text { training in } \\
\text { the use of } \\
\text { digital } \\
\text { textbooks } \\
\text { - Conduct } \\
\text { workshops } \\
\text { for parents } \\
\text { about the } \\
\text { impact of } \\
\text { digital } \\
\text { textbooks on } \\
\text { them and } \\
\text { their } \\
\text { children. }\end{array}$ & $\begin{array}{l}\text { digital } \\
\text { textbooks } \\
\text { - Design and } \\
\text { facilitate } \\
\text { online } \\
\text { interactions } \\
\text { with student, } \\
\text { faculty and } \\
\text { experts in } \\
\text { remote } \\
\text { locations } \\
\text { - Keep } \\
\text { detailed data } \\
\text { on issues } \\
\text { dealing with } \\
\text { access for } \\
\text { further } \\
\text { program } \\
\text { development }\end{array}$ \\
\hline Skill & $\begin{array}{l}\text { - Design } \\
\text { professional } \\
\text { development } \\
\text { for using } \\
\text { digital } \\
\text { textbooks } \\
\text { - Facilitate } \\
\text { after school } \\
\text { learning } \\
\text { communities } \\
\text { in which }\end{array}$ & $\begin{array}{l}\text { - Co-plan, } \\
\text { co-teach, } \\
\text { and co- } \\
\text { assess } \\
\text { lessons that } \\
\text { include } \\
\text { digital } \\
\text { textbooks, } \\
\text { relevant } \\
\text { resources, } \\
\text { and } 21 \mathrm{st}\end{array}$ & $\begin{array}{l}\text { - Make } \\
\text { available } \\
\text { digital } \\
\text { textbook } \\
\text { tutorials } \\
\text { - Build a } \\
\text { collection of } \\
\text { relevant } \\
\text { resources } \\
\text { that enhance } \\
\text { the digital }\end{array}$ & $\begin{array}{l}\text { - Survey } \\
\text { teachers on } \\
\text { professional } \\
\text { development } \\
\text { needs } \\
\text { - Seek } \\
\text { professional } \\
\text { development } \\
\text { in network } \\
\text { administratio } \\
\text { n and new }\end{array}$ & $\begin{array}{l}\text { - Promote a } \\
\text { collection of } \\
\text { professional } \\
\text { learning } \\
\text { digital videos } \\
\text { and } \\
\text { resources } \\
\text { relevant to } \\
\text { digital } \\
\text { textbooks } \\
\text { - Incorporate }\end{array}$ \\
\hline
\end{tabular}




\begin{tabular}{|c|c|c|c|c|c|}
\hline & Teacher & $\begin{array}{l}\text { Instructional } \\
\text { Partner }\end{array}$ & $\begin{array}{l}\text { Resource } \\
\text { Specialist }\end{array}$ & $\begin{array}{l}\text { Program } \\
\text { Leader }\end{array}$ & Even Further \\
\hline & $\begin{array}{l}\text { teachers } \\
\text { participate in } \\
\text { online } \\
\text { learning } \\
\text { experiences }\end{array}$ & $\begin{array}{l}\text { Century } \\
\text { Skills } \\
\text { - Provide } \\
\text { support and } \\
\text { professional } \\
\text { development } \\
\text { for effective } \\
\text { use of digital } \\
\text { textbooks } \\
\text { and relevant } \\
\text { resources. } \\
\text { - Serve as a } \\
\text { model for } \\
\text { using digital } \\
\text { textbooks in } \\
\text { your own } \\
\text { instruction }\end{array}$ & $\begin{array}{l}\text { textbook } \\
\text { curriculum }\end{array}$ & $\begin{array}{l}\text { applications } \\
\text { use } \\
\text { - Educate } \\
\text { parents on } \\
\text { copyright, } \\
\text { safety, and } \\
\text { use of digital } \\
\text { textbooks }\end{array}$ & $\begin{array}{l}\text { digital media } \\
\text { and digital } \\
\text { textbook } \\
\text { activities into } \\
\text { school } \\
\text { television } \\
\text { production } \\
\text { - } \\
\text { Facilitate the } \\
\text { use of } \\
\text { multiple } \\
\text { sources of } \\
\text { digital } \\
\text { content to } \\
\text { construct } \\
\text { unique digital } \\
\text { textbooks }\end{array}$ \\
\hline Policy & $\begin{array}{l}\text { - Educate } \\
\text { students and } \\
\text { teachers on } \\
\text { capacity } \\
\text { limitations, } \\
\text { copyright } \\
\text { and safety } \\
\text { implications } \\
\text { of digital } \\
\text { textbook } \\
\text { applications } \\
\text { Promote } \\
\text { digital } \\
\text { citizenship }\end{array}$ & $\begin{array}{l}\text { • Collect } \\
\text { information } \\
\text { about } \\
\text { instructional } \\
\text { events that } \\
\text { make use of } \\
\text { digital } \\
\text { textbooks } \\
\text { and present } \\
\text { in annual or } \\
\text { quarterly } \\
\text { reports to } \\
\text { administratio } \\
\text { n and school } \\
\text { board } \\
\text { - Participate } \\
\text { on } \\
\text { technology- } \\
\text { planning } \\
\text { committees } \\
\text { that make } \\
\text { decisions } \\
\text { about } \\
\text { technology, } \\
\text { equipment, } \\
\text { and }\end{array}$ & $\begin{array}{l}\text { - Ensure that } \\
\text { collection } \\
\text { policy } \\
\text { pertains to } \\
\text { collecting } \\
\text { and } \\
\text { describing } \\
\text { resources } \\
\text { relevant to } \\
\text { digital } \\
\text { textbooks } \\
\text { - Develop } \\
\text { Acceptable } \\
\text { Use Policies } \\
\text { that include } \\
\text { digital } \\
\text { textbooks }\end{array}$ & $\begin{array}{l}\text { - Determine } \\
\text { future digital } \\
\text { textbook and } \\
\text { application } \\
\text { needs and } \\
\text { communicate } \\
\text { those to } \\
\text { district } \\
\text { personnel }\end{array}$ & $\begin{array}{l}\text { Perform } \\
\text { policy impact } \\
\text { studies and } \\
\text { adjust on an } \\
\text { ongoing } \\
\text { basis } \\
\text { - Get } \\
\text { involved in } \\
\text { state and } \\
\text { national } \\
\text { committees } \\
\text { and } \\
\text { legislative } \\
\text { initiatives } \\
\text { dealing with } \\
\text { digital } \\
\text { textbooks }\end{array}$ \\
\hline
\end{tabular}




\begin{tabular}{|l|l|l|l|l|l|}
\hline & Teacher & $\begin{array}{l}\text { Instructional } \\
\text { Partner }\end{array}$ & $\begin{array}{l}\text { Resource } \\
\text { Specialist }\end{array}$ & $\begin{array}{l}\text { Program } \\
\text { Leader }\end{array}$ & Even Further \\
\hline Motivation & $\begin{array}{l}\text { • Promote } \\
\text { activities that } \\
\text { utilize digital } \\
\text { textbooks } \\
\text { effectively } \\
\text { and } \\
\text { efficiently, } \\
\text { and are } \\
\text { engaging for } \\
\text { learners }\end{array}$ & $\begin{array}{l}\text { resources } \\
\text { teaching } \\
\text { successes } \\
\text { using digital } \\
\text { textbooks } \\
\text { and relevant } \\
\text { resources } \\
\text { with other } \\
\text { teachers } \\
\text { - Facilitate } \\
\text { sharing of } \\
\text { successful } \\
\text { lessons with } \\
\text { other } \\
\text { teachers } \\
\text { Set up } \\
\text { stations in } \\
\text { the library for } \\
\text { individual } \\
\text { and small } \\
\text { group } \\
\text { training }\end{array}$ & $\begin{array}{l}\text { repository of } \\
\text { successful } \\
\text { tessons and } \\
\text { feedback }\end{array}$ & $\begin{array}{l}\text { Create an } \\
\text { research on } \\
\text { student } \\
\text { learning with } \\
\text { digital } \\
\text { textbooks } \\
\text { Collect and } \\
\text { share data } \\
\text { on student } \\
\text { success } \\
\text { using digital }\end{array}$ & $\begin{array}{l}\text { an online } \\
\text { community } \\
\text { for student } \\
\text { learners to } \\
\text { share ideas } \\
\text { and projects } \\
\text { as a result of } \\
\text { using digital } \\
\text { textbooks }\end{array}$ \\
& & $\begin{array}{l}\text { Develop } \\
\text { school-wide } \\
\text { celebrations } \\
\text { that } \\
\text { encourage a } \\
\text { positive } \\
\text { transition to } \\
\text { digital } \\
\text { textbooks }\end{array}$ & \\
\hline
\end{tabular}

Table 2. Teacher librarian leadership roles in digital textbook implementation.

A recent FSU dissertation compared the leadership role of teacher librarians in the adoption of digital textbooks in Florida and South Korea by using the Concerns Based Adoption Model (CBAM) (Kang, 2015). The study revealed that teacher librarians in both places were unconcerned about digital textbooks and more concerned about a multitude of other obligations, activities, or innovations. The CBAM theory anticipates that there will be potential resistance from teacher librarians towards digital textbook implementation in the two locations, and underscore a need for various interventions. Kang (2015) argues that it is urgent to introduce various interventions for specific groups of participants at various stages of concern and provides them.

\section{Implications for Teacher Librarian Education}

As new devices and innovations become available, it would be ideal to have an onsite laboratory where students could experiment with them. If classes are online, link to appropriate videos where new devices are being demonstrated. Students can take the Stages of Concern Questionnaire to find out where they are concerned about an innovation and devise their own intervention strategies to overcome possible resistance to it. Locate a technology innovator and invite them to speak to the class either in person or online. Have 
students create a professional learning network (PLN) for how they will stay abreast of new technology when they begin practice.

As in the case of e-book readers, students could compare and contrast their various features and make a recommendation for which they would purchase for their school library program and justify the decision. Create small group discussions or simulations where students could deliberate about new technology and the implications for being an early adopter. Once again, students could create a convincing presentation for the school board or PTO in order to obtain funding for a new innovation or a sample professional development activity for teachers. Producing new, or adapting of existing lesson plans that integrate a new device into learning standards, is a worthwhile exercise. Students could exchange the lesson plans and develop a portfolio.

\section{Conclusion}

In the past eight years the research in the area of teacher librarian leadership has developed significantly. This foundation provides teacher librarian educators a path to educate the professionals of the next decade in assuming vital leadership roles.

\section{References}

American Association of School Librarians (AASL). (2009). Empowering learners: Guidelines for school library media programs. Chicago: American Library Association.

American Association of School Librarians (AASL) \& Association for Educational Communications and Technology (AECT). (1998). Information power: Building partnerships for learning. Chicago: American Library Association.

Common Sense Media. (2013). Teaching with technology: The promise and reality of the U.S. digital classroom. Retrieved from https://www.graphite.org/blog/teaching-with-technology-the-promise-andreality-of-the-us-digital-classroom

Diekema, A. R. \& Olsen, M. W. (2012). The notion of relevance in teacher information behavior. Proceedings of the American Society for Information Science and Technology, 49(1), 1-9.

Duke, T. S., \& Ward, J. D. (2009). Preparing information literate teachers: A metasynthesis. Library \& Information Science Research, 31, 247-256.

Everhart, N., Mardis, M., \& Johnston, M. P. (2012). National board certified school librarians' leadership in technology integration: Results of a national survey. School Library Media Research, 14. Retrieved from http://ala.org/aasl/aaslpubsandjournals/slmrb/

Everhart, N., Mardis, M., Johnston, M. P., \& Smith, D. (2009). White Paper: From 
District to Desktop: Making the Most of Broadband in Florida Schools.

Florida State University: The PALM Center. Retrieved from

http://www.palmcenter.fsu.edu/Uploads/1/docs/centers/PALM/broadband.pd

$\underline{f}$

Fontichiaro, K. (2011). Nudging toward Inquiry: Formative assessment. School Library Monthly, 27(6). Retrieved from http://www.schoollibrarymonthly.com/curriculum/Fontichiaro2011v27n6p11.html

Harada, V. H., \& Yoshima, J. M. (2006). Assessing learning: The missing piece in instruction? School Library Monthly, 22(7). Retrieved from http://www.schoollibrarymonthly.com/articles/Harada2006v22n7p20.html

Heron, J. (1996). Co-operative inquiry: Research into the human condition. Thousand Oaks, CA: Sage.

Johnston, M. P. (2011). School librarians at technology integration leaders: Enablers and barriers to leadership enactment. (Doctoral Dissertation). Retrieved from Dissertation Abstracts International. (3483677).

Johnston, M. P. (2012). School librarians as technology integration leaders: Enablers and barriers to leadership enactment. School Library Research, 15(1). Retrieved from www.ala.org/aasl/slr

Johnston, M. P. (2015). The school librarian and the technology specialist relationship: The school librarian perspective. Tech Trends.

Kang, J. H. (2015). The leadership role of school librarians in the adoption of digital textbooks: Evaluating school librarians' stages of concerns in Florida and South Korea. (Unpublished doctoral dissertation). Florida State University, Tallahassee, FL.

Kouzes, J. M. \& Posner, B. Z. (2007). The leadership challenge. San Francisco, CA: Jossey-Bass.

Mardis, M. A., ElBasri, T. E., Norton, S. K., \& Newsum, J. (2012). The new digital lives of teachers: A research synthesis and trends to watch. School Libraries Worldwide, 18(1), 70-86.

Mardis, M. A., \& Everhart, N. (2014). Stakeholders as researchers: A multiple case study of using cooperative inquiry to develop and document the formative leadership experiences of new school library professionals. Library and Information Science Research, 36(1) 3-15. 
Mardis, M., Everhart, N., Baker, S. and Newsum, J. (2010). White Paper: From Paper to Pixel: Digital Textbooks in Florida Schools. Florida State University: The PALM Center. Retrieved from: http://www.palmcenter.fsu.edu/Uploads/1/docs/centers/PALM/digital.pdf

National Board for Professional Teaching Standards. (2001). Accomplished teachers taking on new leadership roles in schools. Retrieved from, http://www.nbpts.org/research/archive 3.cfm?id=7

Partnerships Advancing Library Media (PALM) Center, Florida State University (2009). School library media specialist and technology integration survey. Unpublished instrument.

Project Tomorrow. (2014). The new digital playbook: Understanding the spectrum of students' activities and aspirations. Irvine, CA: Project Tomorrow. Retrieved from http://www.tomorrow.org/speakup/SU13DigitalLearningPlaybook StudentR eport.html

Smith, D. (2009). Self-perceptions of leadership potential: A study of teacher-leaders educated to be school library media specialists who lead. (Doctoral Dissertation). Retrieved from Dissertation Abstracts International. (304881527).

Smith, D. (2010). Making the case for the leadership role of school librarians in technology integration. Library Hi Tech, 28(4), 617-631.

Spillane, J. P. (2006). Distributed leadership (1st ed.). San Francisco: Jossey-Bass.

Wolf, M. A., Jones, R., \& Gilbert, D. (2014). Leading beyond the library. Washington, DC: Alliance for Excellent Education.

Zinn, L. P. (1997). Supports and barriers to teacher leadership: Reports of teacher leaders. (Unpublished doctoral dissertation). Retrieved from Dissertation Abstracts International (304369244).

\section{Biographical Notes}

Nancy Everhart is a Professor at the iSchool at Florida State University where she teaches and conducts research in school librarian leadership. She has received over $\$ 4$ million in grants to develop, implement, and research the Project LEAD program. She has written over 80 publications and was the President of the American Association of School Librarians in 2010-2011. Nancy is on the Board of Directors of the International Association of School Librarianship where she serves as the 
Regional Director representing the United States. She received the 2012 IASL School Librarianship Award for her contributions to the profession.

Melissa P. Johnston is an Assistant Professor at The University of Alabama in the School of Library and Information Studies, where she coordinates and teaches graduate courses in the school library media certification program. Johnston worked as a school librarian for 13 years in Georgia before completing her PhD at Florida State University's School of Information. Johnston received the IASL Ken Haycock Leadership Award in 2013 and the IASL Takeshi Murofushi Research Award in 2011 to investigate international school librarian practices. In 2014 Johnston was the corecipient of the Association for Educational Communications and Technology CrossCultural Research Award. Johnston's research and publications focus on school librarians as leaders, the school librarian's role in technology integration, and school librarianship on a global level. 